\title{
Learning from $B_{12}$ enzymes: biomimetic and bioinspired catalysts for eco-friendly organic synthesis
}

\author{
Keishiro Tahara ${ }^{1}$, Ling Pan ${ }^{2}$, Toshikazu Ono ${ }^{3,4,5}$ and Yoshio Hisaeda ${ }^{* 3,4}$
}

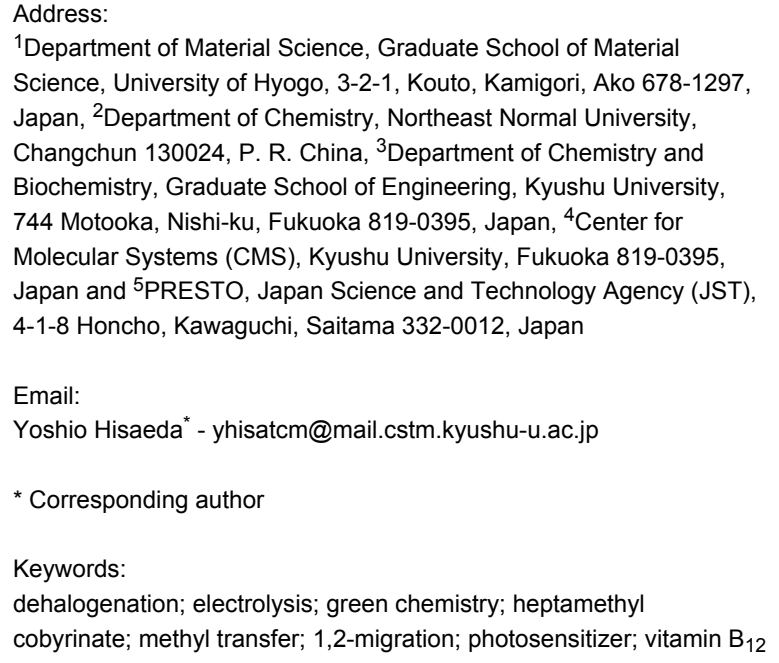

Beilstein J. Org. Chem. 2018, 14, 2553-2567.

doi:10.3762/bjoc. 14.232

Received: 02 June 2018

Accepted: 13 September 2018

Published: 02 October 2018

This article is part of the thematic issue "Cobalt catalysis".

Guest Editor: S. Matsunaga

(c) 2018 Tahara et al.; licensee Beilstein-Institut. License and terms: see end of document.

\begin{abstract}
Cobalamins $\left(\mathrm{B}_{12}\right)$ play various important roles in vivo. Most $\mathrm{B}_{12}$-dependent enzymes are divided into three main subfamilies: adenosylcobalamin-dependent isomerases, methylcobalamin-dependent methyltransferases, and dehalogenases. Mimicking these $\mathrm{B}_{12}$ enzyme functions under non-enzymatic conditions offers good understanding of their elaborate reaction mechanisms. Furthermore, bio-inspiration offers a new approach to catalytic design for green and eco-friendly molecular transformations. As part of a study based on vitamin $\mathrm{B}_{12}$ derivatives including heptamethyl cobyrinate perchlorate, we describe biomimetic and bioinspired catalytic reactions with $\mathrm{B}_{12}$ enzyme functions. The reactions are classified according to the corresponding three $\mathrm{B}_{12}$ enzyme subfamilies, with a focus on our recent development on electrochemical and photochemical catalytic systems. Other important reactions are also described, with a focus on radical-involved reactions in terms of organic synthesis.
\end{abstract}

\section{Review}

\section{Introduction}

1-1. Redox and coordination chemistry of $B_{12}$

Cobalamins $\left(\mathrm{B}_{12}\right)$ are naturally occurring cobalt complexes with unique structures that play various important roles in vivo [1-5]. In $\mathrm{B}_{12}$, the cobalt center is coordinated by four equatorial lower axial ligand (Figure 1a) [6-8]. The cobalamin with an upper ligand is termed vitamin $\mathrm{B}_{12}$ (a cyanide group), methylpyrroles of the corrin ring and 2,3-dimethylbenzimidazole as a cobalamin (a methyl group), and adenosylcobalamin (an adenosyl group), respectively. The oxidation state of cobalt ions 


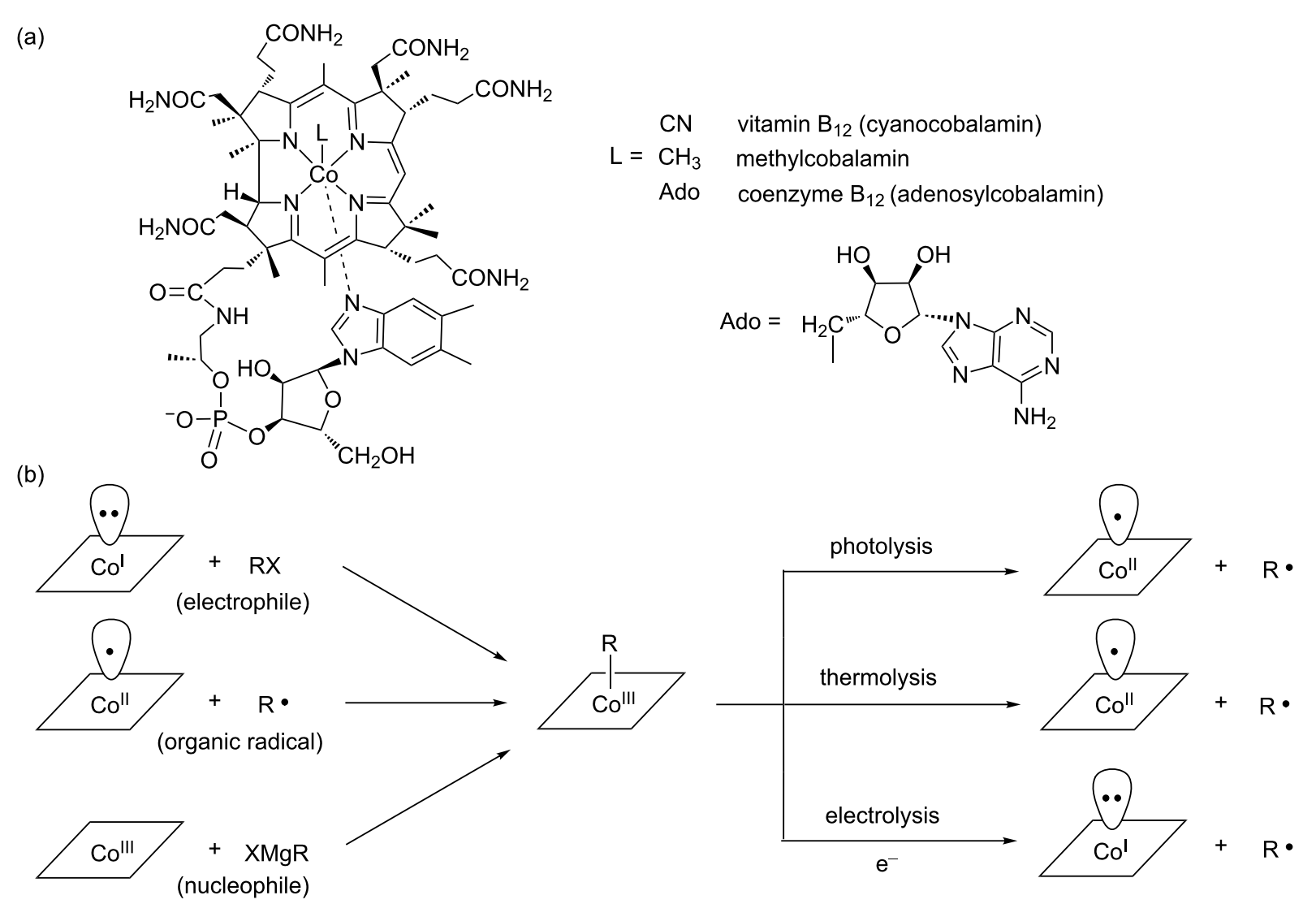

Figure 1: (a) Structure and (b) reactivity of $B_{12}$.

in $B_{12}$ ranges from +1 to +3 . Each oxidation state of cobalamins exhibits quite different ligand-accepting abilities and reactivities. Cob(III)alamins strongly favor 6-coordination with 2,3-dimethylbenzimidazole in homogeneous solutions at physiological $\mathrm{pH}$ (denoted as base-on form). In particular, cob(III)alamins with upper alkyl ligands are quite interesting because of their structural relevance to methylcobalamin and adenosylcobalamin (coenzyme $\mathrm{B}_{12}$ ) that serve as organometallic cofactors in $\mathrm{B}_{12}$-dependent enzymes. The photolysis (thermolysis) of alkylcob(III)alamins leads to the formation of the corresponding alkyl radical and cob(II)alamin with homolytic Co(III)-C bond cleavage (Figure 1b). This high lability is attributed to a relatively weak $\mathrm{Co}$ (III)-C bond, as exemplified by its bond dissociation energies of $30 \mathrm{kcal} / \mathrm{mol}$ in coenzyme $\mathrm{B}_{12}$ and $37 \mathrm{kcal} / \mathrm{mol}$ in methylcobalamin in base-on forms [9]. Cob(II)alamin favors 5-coordination in the homogeneous solutions at physiological $\mathrm{pH}$ [10]. It is paramagnetic and has an unpaired electron in the axial $\mathrm{d} z^{2}$ orbital. It acts as a high efficient "radical trap" and reacts with alkyl radicals to yield alkylcob(III)alamin (Figure 1b). Four-coordinated cob(I)alamin has a paired electron in the axial $\mathrm{d} z^{2}$ orbital, resulting in high nucleophilicity with a Pearson constant of 14 [11]. It is slightly basic, with a $\mathrm{p} K_{\mathrm{a}}$ lower than 1 for the $\mathrm{Co}-\mathrm{H}$ complex [12]. The "supernucleophilic" cob(I)alamin is found in many enzymes such as methionine synthetases, adenosyltransferases, and reductive dehalogenases. In addition, the reactivity of cob(I)alamin has been investigated using various electrophiles such as alkyl halides [13], vinyl halides [14-16], aryl halides $[17,18]$ and epoxides $[19,20]$ in homogeneous solutions (Figure 1b).

\section{1-2. Design of biomimetic and bioinspired $B_{12}$ catalytic systems}

Schematic representations of $\mathrm{B}_{12}$ enzymes and enzyme-involving systems are shown in Figure 2a. The remarkable in vivo and in vitro characters of $\mathrm{B}_{12}$ are summarized as follows:

1. $\mathrm{B}_{12}$ shows good accessibility to $\mathrm{Co}(\mathrm{I})$ species with a redox potential (the $\mathrm{Co}(\mathrm{II}) / \mathrm{Co}(\mathrm{I})$ couple in the base-off form) of $-500 \mathrm{mV}$ vs the standard hydrogen electrode [21], because of the monoanionic corrin ligand.

2. $B_{12}$ is reduced to $\mathrm{Co}(\mathrm{I})$ species in the active center by reductases in sustainable processes.

3. The partially $\pi$-conjugated system of the corrin ring is less easy to be adducted by free radicals than those of porphyrins. 
(a)

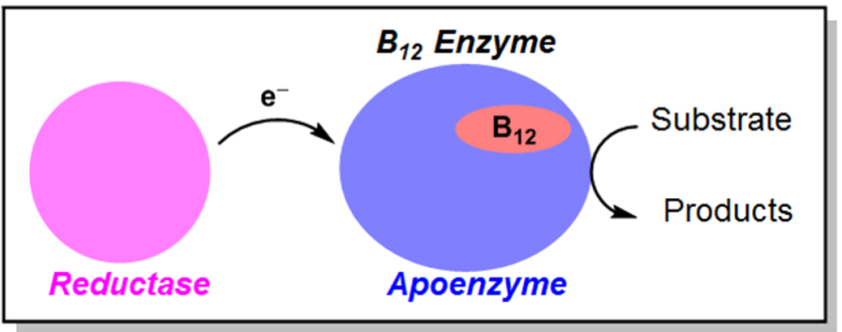

(b) Artificial Reductants
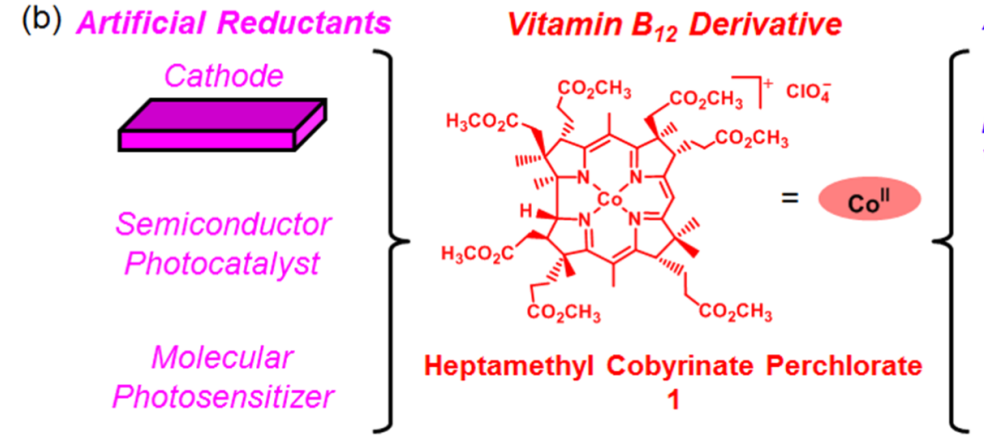

Alternatives to Apoenzyme

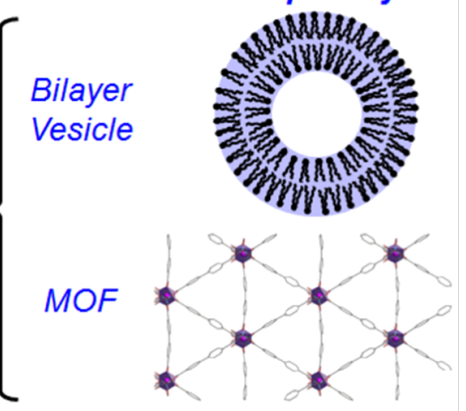

Figure 2: (a) Schematic representation of $B_{12}$ enzyme-involving systems. (b) Construction of biomimetic and bioinspired catalytic systems by combining functional equivalents of $B_{12}$ enzyme-involving systems as components.

4. $\mathrm{B}_{12}$ is bound to a number of proteins and acts as a module.

5. Different chemical functions of $\mathrm{B}_{12}$ are exploited by bound apoenzymes.

6. $\mathrm{B}_{12}$ is recycled or reactivated in vivo as observed in methyonine synthetases.

Understanding the mechanisms of $\mathrm{B}_{12}$ enzyme reactions and the role of $B_{12}$ is very important from the viewpoint of bioinorganic and organometallic chemistry, organic syntheses, and catalysts. Despite extensive research, reproducing $\mathrm{B}_{12}$ enzyme reactions in vitro had been difficult in homogenous solutions.

Construction of sustainable catalytic systems inspired by $\mathrm{B}_{12}$ enzymes is another important issue that must be addressed for green chemistry. Due to the above-mentioned unique redox and coordination chemistry, vitamin $\mathrm{B}_{12}$ and its derivatives [22] are used as effective homogenous catalysts in various organic reactions [23-25], although an excess of chemical reductants are often used to activate $\mathrm{B}_{12}$ to the $\mathrm{Co}(\mathrm{I})$ species. Green catalytic systems capable of activating $B_{12}$ have not been reported in the literature, with the exception of electrocatalytic systems [26,27]

To achieve functional simulations of $\mathrm{B}_{12}$ enzymes under nonenzymatic conditions, our strategy is to fabricate the artificial enzymes by combining a functional equivalent of $\mathrm{B}_{12}$ and that of an apoenzyme (Figure 2b). We have been exploring the utility of hydrophobic $\mathrm{B}_{12}$ model complexes, such as heptamethyl cobyrinate perchlorate $\mathbf{1}$, that possess ester groups in place of the peripheral seven-amide moieties [28,29]. 1 was developed by Eschenmoser et al. as a model complex for the total synthesis of vitamin $B_{12}$ [30]. Indeed, in the crystal structure, 1 maintained the same corrin framework as natural $\mathrm{B}_{12}$ [31]. We combined the hydrophobic $\mathrm{B}_{12}$ derivatives with bilayer vesicles [32,33], a protein [34], organic polymers [35-40], and metal organic frameworks (MOFs) [41]. Furthermore, to construct green catalytic systems inspired by $\mathrm{B}_{12}$ enzymes, we combined the hydrophobic $\mathrm{B}_{12}$ derivatives with a functional equivalent of reductases. In the resultant catalytic systems, the $\mathrm{Co}(\mathrm{I})$ species was generated through electron transfers from the cathodes [42,43], semiconductors [44], or molecular photosensitizers [45] to the $\mathrm{B}_{12}$. In this review, we summarize the biomimetic and bioinspired catalytic reactions with $\mathrm{B}_{12}$ enzyme functions, with a focus on our recent work on electrochemical and photochemical systems.

\section{1,2-Migrations of functional groups}

Enzymes using radical species are models of good catalysts for chemists because they efficiently mediate difficult organic reactions under mild conditions [46-51]. In some catalysis mediated by $\mathrm{B}_{12}$ enzymes, the high reactivity of the adenosyl radical is exploited for isomerization. The microenvironments provided by the apoenzymes activate and cleave the $\mathrm{Co}$ (III)-C bond of the $\mathrm{B}_{12}$ coenzyme $\mathrm{B}_{12}$ in a homolytic fashion to produce an adenosyl radical $[52,53]$. In methylmalonyl-CoA mutase (MMCM), the conversion from $R$-methylmalonyl-CoA to succinyl-CoA (Scheme 1a) starts with hydrogen abstraction by the adenosyl radical. 
(a)

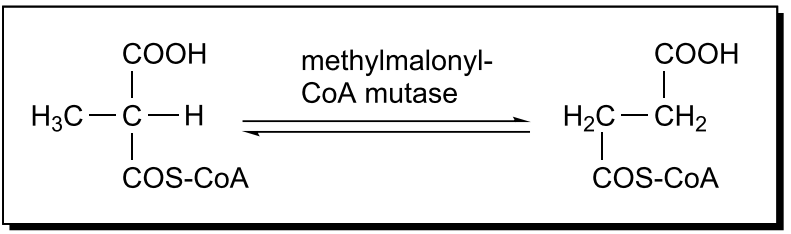

(b) $\stackrel{\mathrm{CO}_{2} \mathrm{C}_{2} \mathrm{H}_{5}}{\mathrm{H}_{2} \mathrm{C}}-\underset{\mathrm{Br}}{\mathrm{C}}-\mathrm{CH}_{3}$
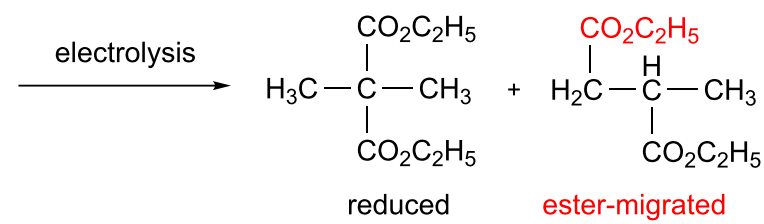

product
ester-migrated product

turnover

vs SCE

$\begin{array}{ll}1 & -1.0 \mathrm{~V}, h v \\ 1 & -2.0 \mathrm{~V}\end{array}$

$10 \%$

trace

number/h

$15 \%$

$80 \%$

1.6

20

Scheme 1: (a) Carbon-skeleton rearrangement mediated by a coenzyme $B_{12}$-depenedent enzyme. (b) Electrochemical carbon-skeleton rearrangement mediated by 1.

\section{2-1. Electrochemical catalytic reactions}

We deeply investigated the electrochemical catalytic reactions mediated by 1 and related complexes and succeeded in the functional simulations of MMCM-type 1,2-migration reactions [42]. For example, when 2,2-bis(ethoxycarbonyl)-1-bromopropane was selected as a model substrate, the 1,2-migration of carboylic ester $(80 \%)$ and some simple reduction product $(20 \%)$ were obtained under controlled-potential electrolysis at $-2.0 \mathrm{~V}$ vs SCE in the presence of catalyst $\mathbf{1}$ in DMF (Scheme 1b) [54]. There were different ratios for the simple reduced product and the ester-migrated product, depending on the reaction conditions. Mechanistic investigations revealed that the formation of the two-electron-reduced species of Co(III)-monoalkylated complex of $\mathbf{1}$ was vital for carbon-skeleton rearrangement reac- tions. It was also discovered that the 1,2-migration of the carboxylic ester group proceeded via an anionic intermediate. To clarify the migratory aptitude of the functional groups, several kinds of substrates with an electron-withdrawing group were utilized. The yields of the migrated products increased in the order of $\mathrm{CN}<\mathrm{CO}_{2} \mathrm{R}<\mathrm{COR}$ [54]. For alkyl halides with two carboxylic ester groups that differ in their bulkiness, the yields of the migrated products are higher for the smaller ester group [55].

Furthermore, we succeeded in tuning selectivity in the 1,2migration of a functional group mediated by $\mathbf{1}$ by controlling the electrolysis potential (Scheme 2) [56]. The electrolysis of diethyl 2-bromomethyl-2-phenylmalonate at $-2.0 \mathrm{~V}$ vs

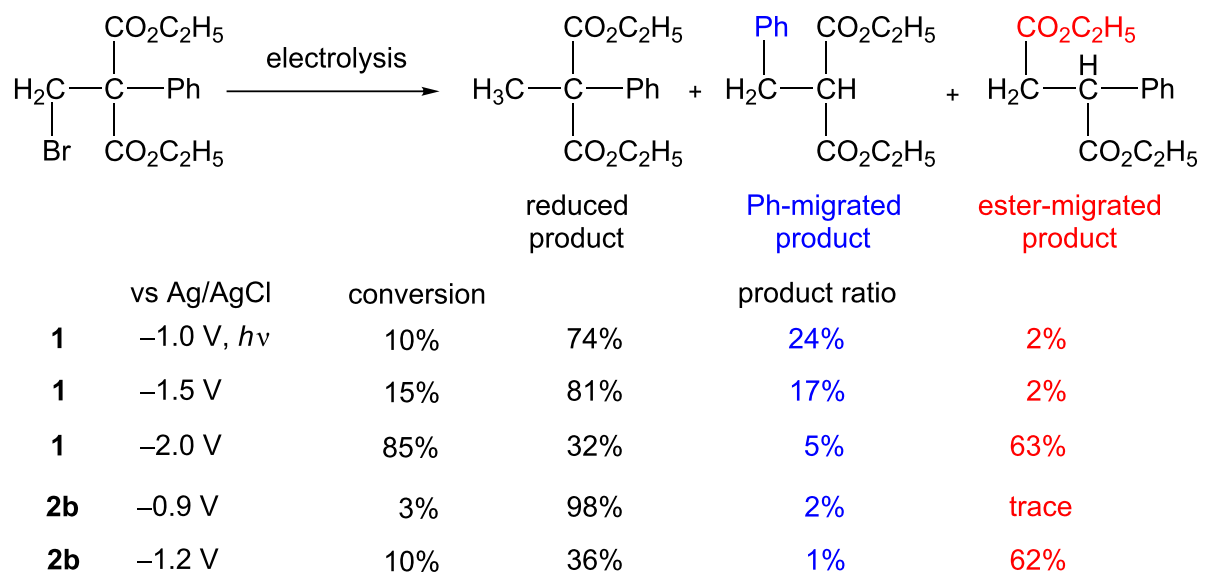


$\mathrm{Ag} / \mathrm{AgCl}$ yielded carboxylic ester migrated product as the major product. Conversely, the electrolysis of the substrate at $-1.0 \mathrm{~V}$ vs $\mathrm{Ag} / \mathrm{AgCl}$ through light irradiation, as well as at $-1.5 \mathrm{~V}$ vs $\mathrm{Ag} / \mathrm{AgCl}$ in the dark, yielded the simple reduced product and the phenyl migrated product. The cathodic reactivity of the monoalkylated complex of $\mathbf{1}$ was found to be critical to the selectivity of the migrating group.

Interestingly, the electrochemical carbon-skeleton rearrangement reactions were successfully mediated by simple $\mathrm{B}_{12}$ model complexes 2 (Figure 3). The imine/oxime-type square planar ligands of cobalt complexes $\mathbf{2}$ are superior to porphyrin ligands in terms of the model for the corrin framework of $\mathrm{B}_{12}$; both the imine/oxime-type and corrin ligands are monoanionic [57-60]. The imine/oxime-type cobalt complex 2 can be isolated in both the monoalkylated and dialkylated forms $[59,60]$. This is in contrast to $1 ; 1$ cannot be dialkylated because of steric hindrances [42]. The Co(III)-monoalkylated complex can be electrochemically reduced to form $\mathrm{Co}(\mathrm{I})$ species and a $\mathrm{Co}(\mathrm{III})-$ dialkylated complex through disproportionation. The resulting Co(III)-dialkylated complex shows different electrochemical reactivity. It can be electrochemically oxidized to form the Co(III)-monoalkylated complex. These electrochemical reactivities are exemplified by those of the $\mathrm{Co}$ (III) $-\mathrm{CH}_{3}$ and $\mathrm{Co}(\mathrm{III})-\left(\mathrm{CH}_{3}\right)_{2}$ complexes of compound 2a in Figure 3. In the electrolysis, the reduction of the $\mathrm{Co}(\mathrm{III})$-monoalkylated complex and the oxidation of the Co(III)-dialkylated complex proceeded at the cathode and anode, respectively [61]. These processes were coupled to achieve the 1,2-migration of functional groups. Further investigations with diethyl 2-bromomethyl-2-phenylmalonate as a substrate confirmed that the carboxylic ester-migrated product was formed via not a radical, but a cationic intermediate that was generated by the fragmentation to the monoalkylated complex at the anode (Scheme 2).

\section{2-2. Artificial enzyme-mediated reactions}

A vesicle-type $B_{12}$ artificial enzyme was constructed by combining bilayer vesicles composed of synthetic lipids and alkylated complexes of heptapropyl cobyrinate (Scheme 3) [32,33]. The alkylated $\mathrm{B}_{12}$ model complexes were introduced into the vesicle in aqueous solutions through non-covalent hydrophobic interactions and irradiated with a $500 \mathrm{~W}$ tungsten lamp to result in the homolytic cleavage of the $\mathrm{Co}(\mathrm{III})-\mathrm{C}$ bonds. The carbonskeleton rearrangements were achieved in the vesicle due to cage effects in the apoenzyme model. Conversely, such reactions hardly proceeded in homogenous solutions. The yields of the migration products increased in order of $\mathrm{CN} \sim \mathrm{CO}_{2} \mathrm{C}_{2} \mathrm{H}_{5}<$ $\mathrm{COCH}_{3}$. A cyclophane-type $\mathrm{B}_{12}$ artificial enzyme also mediated similar carbon-skeleton rearrangements [32].

We developed another artificial enzyme composed of human serum albumin (HSA) and heptapropyl cobyrinate [34]. It is known that HSA acts as a carrier for in vivo hydrophobic molecules. Hydrophobic $\mathrm{B}_{12}$ model complexes were successfully incorporated into the HSA. The incorporated amounts increased as the hydrophobicity of the $\mathrm{B}_{12}$ model complexes increased. The hydrophobicity can be varied through chemical modification of the peripheral ester groups placed at the peripheral sites of the corrin skeleton. The HSA microenvironments increased the yield of the acetyl-migrated product compared with the homogenous conditions of the methanol or benzene solutions

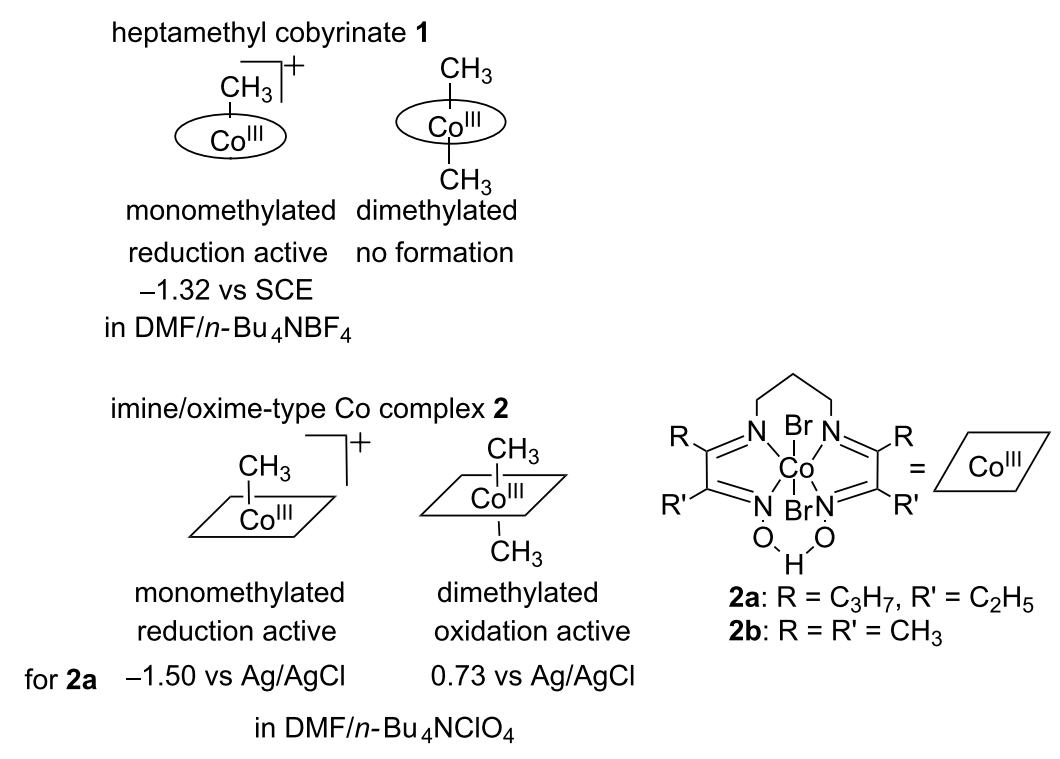

Figure 3: Key electrochemical reactivity of $\mathbf{1}$ and $\mathbf{2}$ in methylated forms. 
<smiles>CCOC(C)(C)C(C)(CC(Cl)Cl)OCC</smiles><smiles>CCOC(C)(C)C(C)(C)OCC</smiles>

Reduced Product<smiles>CCOC(C)(C)C(C)=O</smiles>

Ester-migrated Product

Product Ratio

$75 \%$

$9 \%$

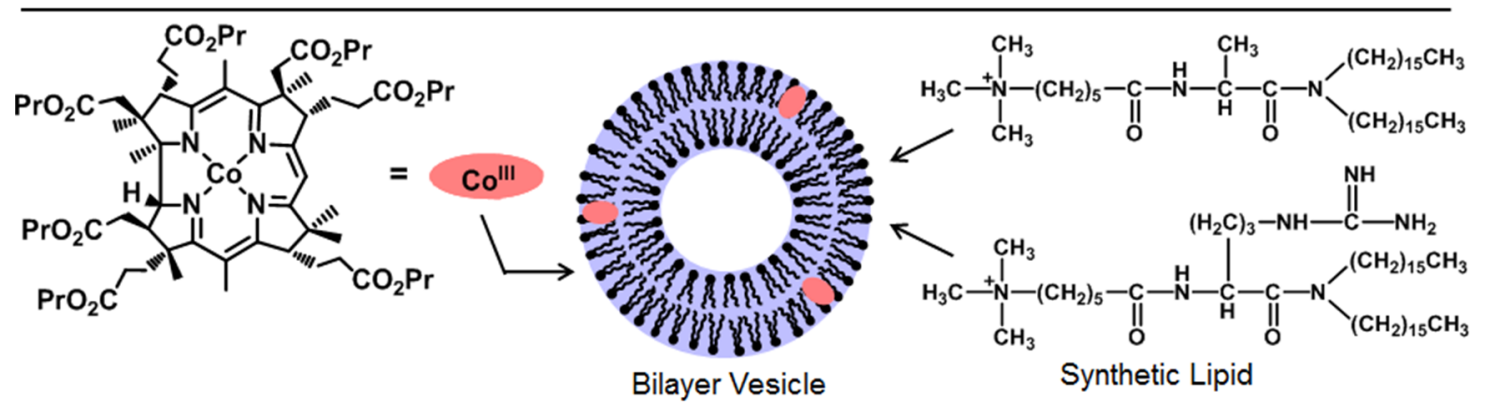

Scheme 3: Carbon-skeleton arrangements mediated by $\mathrm{B}_{12}$-vesicle artificial enzymes.

(Scheme 4). This increase resulted from the effects of suppression of molecular motion and the desolvation of the $\mathrm{B}_{12}$ model complex in HSA.

MOFs are a class of crystalline materials constructed from metal connecting nodes and molecular building blocks [62-64]. To explore the utilities of the microenvironments provided by MOFs for $\mathrm{B}_{12}$ catalytic reactions, a new MOF $\left\{\mathrm{Zn}_{4} \mathrm{Ru}_{2}(\mathrm{bpdc})_{4}\right.$. $\left.4 \mathrm{NH}_{2}\left(\mathrm{CH}_{3}\right)_{2} \cdot 9 \mathrm{DMF}\right\}_{n}\left(\mathrm{H}_{2}\right.$ bpdc $=4,4$ '-biphenyldicarboxylic acid) was prepared by the reaction of $\mathrm{H}_{2} \mathrm{bpdc}, \mathrm{Ru}(\mathrm{bpy})_{2} \mathrm{Cl}_{2}$, and a zinc source under solvothermal conditions (bpy $=2,2^{\prime}$ bipyridine, Scheme 5) [41]. The molecular photosensitizer $\left[\mathrm{Ru}(\mathrm{bpy})_{3}\right]^{2+}$ was incorporated into the MOF through adsorption to form Ru@MOF, accompanied by a color change. Furthermore, 1 was effectively immobilized on Ru@MOF, as was confirmed through ESR measurements. The resultant heterogeneous hybrid catalyst $\mathrm{B}_{12}-\mathrm{Ru} @ \mathrm{MOF}$ successfully mediated the photochemical carbon-skeleton arrangement. Previous studies had demonstrated that the hemolytic cleavage of the Co(III)-C bond of the alkylated complex of 1 generated $\mathrm{Co}$ (II) species and an alkyl radical intermediate A [54]. The prolonged lifetime of the radical intermediate A could be provided by the channel of MOF, enabling conversion to the acetylmigrated radical B. The radicals A and B may abstract hydrogen radicals to form the reduced product and the acetylmigrated product, respectively. It was noticeable that the catalytic cycle for 1,2-migration was constructed for the $\mathrm{B}_{12}$ $\mathrm{Ru} @$ MOF system. This stands in contrast to the stoichiometric reactions in the previous $\mathrm{B}_{12}$ artificial enzymes. Furthermore, the catalytic process of the $\mathrm{B}_{12}-\mathrm{Ru} @ \mathrm{MOF}$ system is visiblelight-driven through the use of $\left[\mathrm{Ru}(\mathrm{bpy})_{3}\right]^{2+}$ as an alternative to reductases. This serves as a simplified analogy for the $\mathrm{B}_{12}$ en-<smiles>CCOC(=O)CC(C)(CC(C)(C)C(=O)OCC)C(=O)OCC</smiles>

$\begin{array}{cccc}\text { methanol } & 90 \% & 10 \% & \text { trace } \\ \text { benzene } & 87 \% & 13 \% & \text { trace } \\ \text { HSA } & 32 \% & 68 \% & \text { trace }\end{array}$


(a)

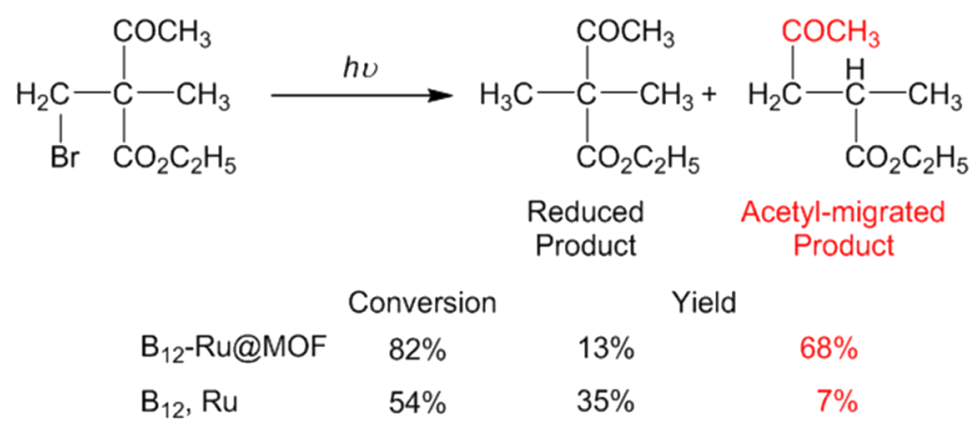

(b)

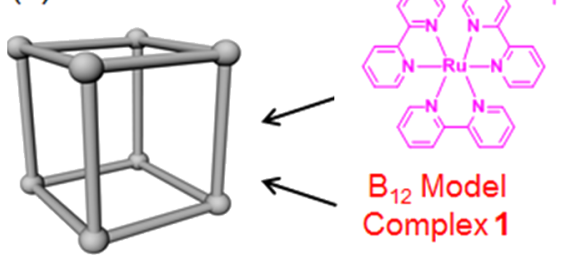

$\left\{\mathrm{Zn}_{4} \mathrm{Ru}_{2}(\mathrm{bpdc})_{4} \cdot 4 \mathrm{NH}_{2}\left(\mathrm{CH}_{3}\right)_{2} \cdot 9 \mathrm{DMF}\right\}_{\mathrm{n}}$

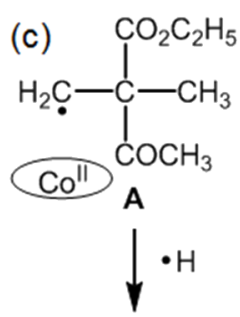

Reduced Product<smiles>[Y]PC(=O)CC(C)(C(=O)OC)C(=O)OC</smiles>

Acetyl-migrated Product

Scheme 5: Photochemical carbon-skeleton arrangements mediated by $\mathrm{B}_{12}-\mathrm{Ru} @ \mathrm{MOF}$.

zyme-involving system (Figure 2a). The $\mathrm{B}_{12}-\mathrm{Ru} @ \mathrm{MOF}$ is the best system for the functional simulation of MMCM among our $\mathrm{B}_{12}$ artificial enzymatic systems.

\section{Methyl transfer reactions}

The $\mathrm{B}_{12}$-dependent methionine synthase catalyzes the methyl transfer reaction as shown in Scheme 6a. In the active center of the enzyme, cob(I)alamin accepts the methyl group from methyltetrahydrofolate $\left(\mathrm{CH}_{3}-\mathrm{H} 4\right.$-folate $)$ and the resultant methylcobalamin donates it to homocysteine $[65,66]$. Constructing the methyl transfer cycle under non-enzymatic conditions is a challenging issue for chemists. Here, we describe model studies of the methylation of $\mathrm{B}_{12}$ derivatives and methyl transfer from methylated $\mathrm{B}_{12}$ derivatives. $\mathrm{Zn}^{2+}$ ions were considered as the essential cofactors in the enzymatic reactions reported by many researchers [67-69].

\section{3-1. Methyl transfer to thiols}

Chemical reductants such as $\mathrm{NaBH}_{4}$ or electrochemical reduction could provide $\mathrm{Co}(\mathrm{I})$ species, so that $\alpha$-methylated and $\beta$-methylated $\mathrm{B}_{12}$ could be formed by the oxidative addition reaction with a methyl donor. The supernucleophile Co(I) species readily react with various methyl halides such as methyl iodide to form a methyl-cobalt complex. Moreover, methanol could also serve as a methyl donor after the activation of the $\mathrm{OH}$ group by a Lewis acid such as $\mathrm{Zn}^{2+}[70,71]$. Thiols could also mediate the methylation of $\mathbf{1}$ with methyl iodide or methyl tosylate $\left(\mathrm{TsOCH}_{3}\right)$ as the methyl donor [72]. Kräutler et al. found an equilibrium methyl transfer between methylcobalamin and the methylated complex of 1 resulting in cob(II)alamin and $\beta$-methyl heptamethyl cob(III)yrinate. Such a thermal equilibration takes 16 days at room temperature [73].

Keese et al. successfully constructed a complete methyl transfer cycle from methylamines to 1-hexanethiol as an excellent bioinspired system. The use of $\mathrm{Zn}$ and $\mathrm{ZnCl}_{2}$ in refluxing ethanol was vital for the bioinspired methyl transfer [74]. Recently, we developed a catalytic methyl transfer system for the first time through electrolysis under non-enzymatic conditions. The methyl transfer from $\mathrm{TsOCH}_{3}$ to 1-octanethiol was mediated by controlled-potential electrolysis at $-1.0 \mathrm{~V}$ vs $\mathrm{Ag} / \mathrm{AgCl}$ in the presence of 1 at $50{ }^{\circ} \mathrm{C}$ (Scheme 6b) [75]. The $\mathrm{Zn}$ plate was used as a sacrificial anode and the resultant $\mathrm{Zn}^{2+}$ ions was vital for the activation of 1-octanethiol [76]. A similar reaction was successfully mediated by the imine/oxime-type cobalt complex $\mathbf{2 a}$ using zinc powder [77].

\section{3-2. Methyl transfer to inorganic arsenic for the detoxification of arsenic}

The wide utilization of inorganic arsenics causes large-scale environmental pollution, resulting in very chronic diseases [78]. 
(a)

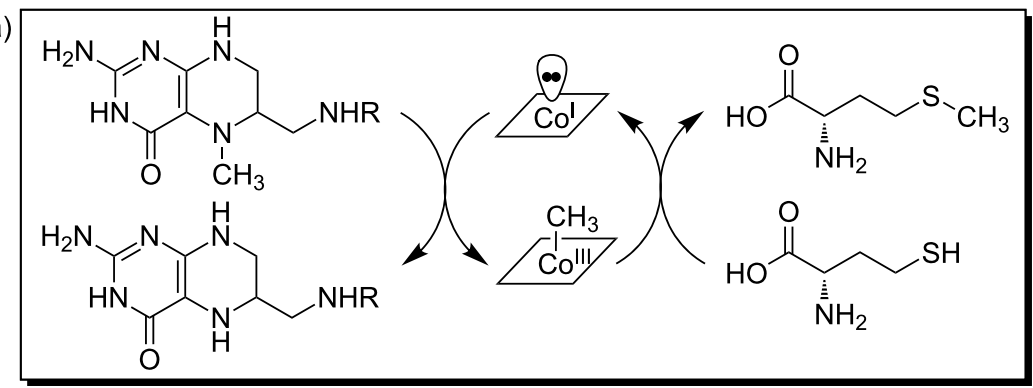<smiles>[R]Cc1ccc(C(=O)NC(CC(C)C(=O)O)C(=O)O)cc1</smiles>

(b)

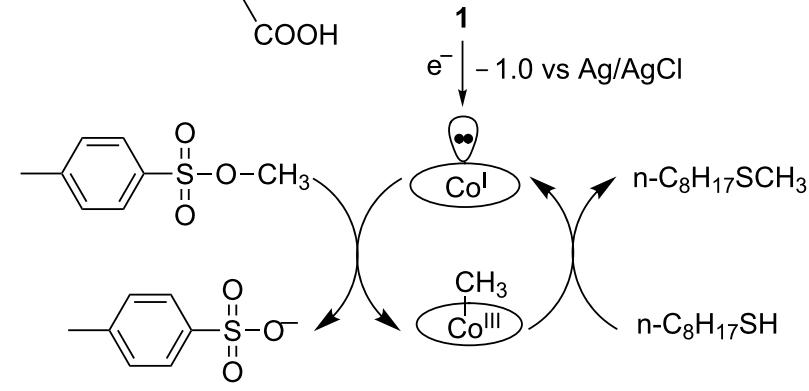

Scheme 6: (a) Methyl transfer reaction mediated by $\mathrm{B}_{12}$-dependent methionine synthase. (b) Methyl transfer reaction from $\mathrm{TsOCH}_{3}$ to 1 -octanthiol mediated by 1 .

However, it was known that the toxicity of organic arsenics is generally much lower than inorganic ones. For example, the acute toxicity of arsenobetaine (AB) is about one threehundredth that of arsenic trioxide [79]; trimethylarsine oxide (TMAO) that is an intermediate in the synthesis of AB also has lower toxicity than inorganic arsenics. Moreover, inorganic arsenics could be converted to methylated arsenics via human or animal metabolism involving a methyltransferase and a reductase [80-82]. Thus, biomimetic transformation from inor- ganic arsenics to organic arsenics via methyl transfer could be an eco-friendly methodology for the detoxification of arsenic. The $\mathrm{B}_{12}$-mimetic methyl transfer reaction for the detoxification of inorganic arsenics has recently been developed. The highly toxic $\mathrm{As}_{2} \mathrm{O}_{3}$ was transformed to $\mathrm{AB}$ via TMAO under mild conditions, as shown in Scheme 7 [83,84]. High efficiency transformation of $\mathrm{As}_{2} \mathrm{O}_{3}$ to TMAO was newly achieved with methylated complex of $\mathbf{1}$ as a methyl donor and GSH as a reductase model.

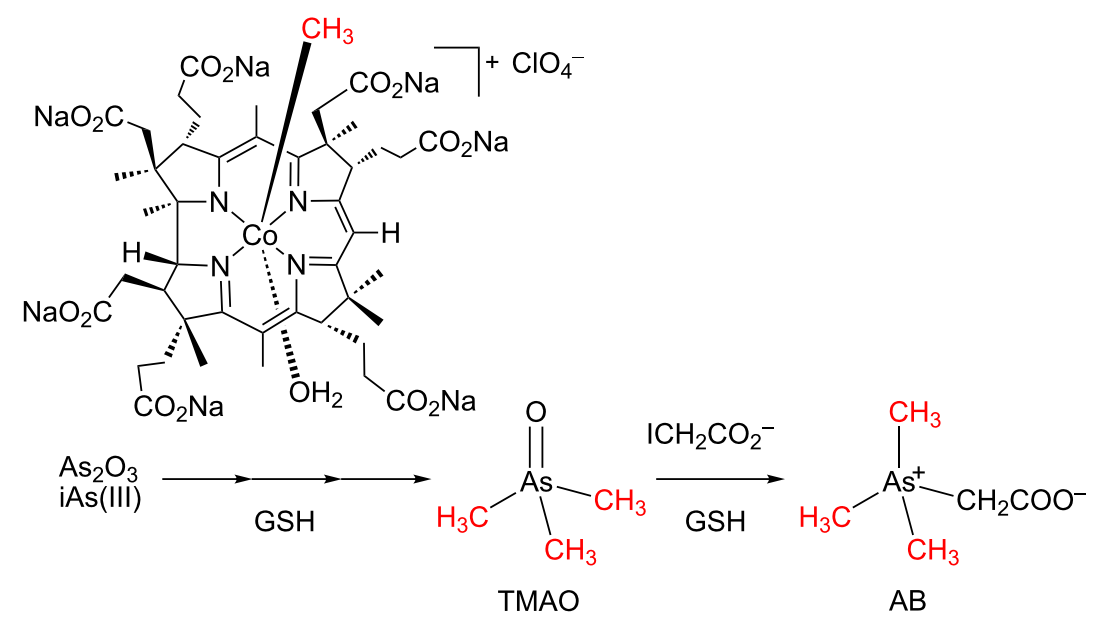

Scheme 7: Methyl transfer reaction for the detoxification of inorganic arsenics. 
The methyl transfer reaction to $\mathrm{As}_{2} \mathrm{O}_{3}$ was first examined at $37{ }^{\circ} \mathrm{C}$ in Tris- $\mathrm{HCl}$ buffer for $24 \mathrm{~h}$. A methylated complex of $\mathbf{1}$ was proved to be more efficient than the naturally occurring methylcobalamin [84]. More than $95 \%$ of $\mathrm{As}_{2} \mathrm{O}_{3}$ was converted into methylarsonic acid (MMA, 67.8\%), dimethylarsonic acid (DMA, $27.2 \%$ ), and TMAO $(0.1 \%)$ in the reaction of 1, whereas only $20 \%$ conversion of $\mathrm{As}_{2} \mathrm{O}_{3}$ was observed in the reaction of methylcobalamin with lower methylated MMA $(17.2 \%)$ and DMA (2.8\%) as products. When the reaction of the methylated complex of $\mathbf{1}$ was performed at $100{ }^{\circ} \mathrm{C}$ in Tris- $\mathrm{HCl}$ buffer for $2 \mathrm{~h}, \mathrm{As}_{2} \mathrm{O}_{3}$ was methylated to TMAO with much as $99 \%$ yield [83]. Combined with the nearly quantitative conversion of TMAO to AB in the presence of GSH and iodoacetic acid in phosphoric acid-citric acid buffer at $37{ }^{\circ} \mathrm{C}$, a safe and eco-friendly detoxification of inorganic arsenics was developed via methyl transfer reactions mediated by biomimetic vitamin $\mathrm{B}_{12}$.

\section{Dehalogenation reactions}

"Dehalorespiration" is also a model of good catalysts for chemists because the anaerobic metabolism of microbes couples the dehalogenation of organic halides with energy conservation [85]. In some electron transport chains, reductive dehalogenases contain $\mathrm{B}_{12}$ derivatives as cofactors [86]. The reductive dehalogenase originating from the anaerobic bacteria, Sulfurospiririllum multivorans, uses 1,1,2,2-tetrarchloroethene as a terminal electron acceptor to be reduced to trichloroethene (Scheme 8a) [87]. In electron transport chains, reductases reduce the $\mathrm{Co}(\mathrm{II})$ species of the $\mathrm{B}_{12}$ cofactor to the $\mathrm{Co}(\mathrm{I})$ species in the active site of reductive dehalogenases [88]. The Co(I) species is a key form for electron transfer to a substrate.

\section{4-1. Choice of alternatives to reductases}

Although anaerobic microbes can be applied to remediation technologies, the dehalogenation abilities of microbes are equal to the intrinsic abilities of nature in principle. Chemical methods are considered as efficient techniques to directly degrade halogenated pollutants. Completely mimicking the complicated dehalorespiration systems requires tedious efforts. The concept of bioinspired chemistry would be an effective methodology to design sustainable systems. To construct good

(a)

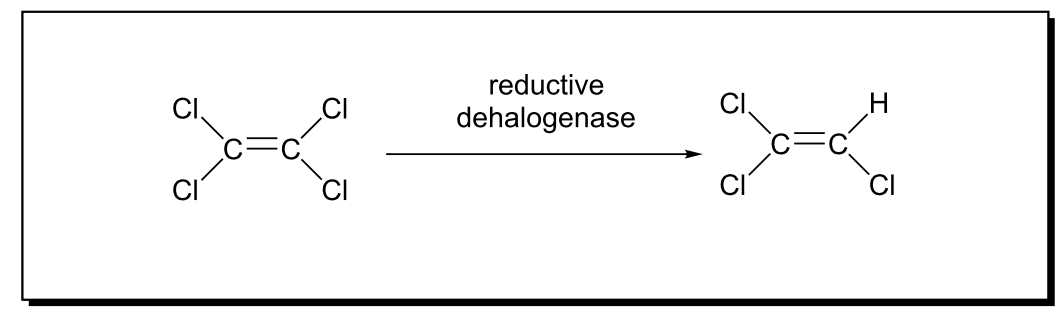

(b)<smiles></smiles><smiles>Clc1ccc(C(c2ccc(Cl)cc2)C(Cl)(Cl)Cl)cc1</smiles>

82
(E)-TTDB

$25 \%$
(Z)-TTDB

$12 \%$

Scheme 8: (a) Dechlorination of 1,1,2,2-tetrarchloroethene mediated by a reductive dehalogenase. (b) Electrochemical dechlorination of DDT mediated by 1 . 
catalytic dehalogenation systems, the key process is the reduction of $\mathrm{Co}(\mathrm{II})$ species of $\mathrm{B}_{12}$ derivatives to the $\mathrm{Co}(\mathrm{I})$ species in sustainable processes.

Electroorganic synthesis is considered an eco-friendly method for synthetic organic chemistry [89-91]. Clean redox events between electrodes and substrates can be achieved without any chemical redox reagents. The use of mediators enables energy savings with mild applied potentials or small amounts of electricity. We constructed electrochemical catalytic systems for dehalogenation of alkyl halides using $\mathbf{1}$. The electron transfer from reductases to $B_{12}$ was replaced with that from the cathodes to $\mathrm{B}_{12}$ derivatives [43].

Light-driven organic transformations attract great attention due to their relevance to photosynthesis in nature as an ideal sustainable system [92-94]. In this context, we constructed light-driven catalytic systems using 1 by replacing reductases with semiconductor photosensitizers and molecular photosensitizers. For example, we reported an ultraviolet-light-driven system using titanium dioxide $\left(\mathrm{TiO}_{2}\right)$ semiconductor [95-101]. The conductive band electron of $\mathrm{TiO}_{2}\left(E_{\text {red }}=-0.5 \mathrm{~V}\right.$ vs NHE in neutral water $)$ could reduce 1 to form $\mathrm{Co}(\mathrm{I})$ species upon irradiation with ultraviolet (UV) light. We also reported a visible-light-driven system with a molecular photosensitizer such as $\mathrm{Ru}(\mathrm{bpy})_{3}{ }^{2+}$ $[39,40,102,103]$, cyclometalated iridium(III) complexes [104], and organic red dyes [105-107].

\section{4-2. Dechlorination of DDT and related compounds}

We developed an electrochemical catalytic system for the dechlorination of 1,1-bis(4-chlorophenyl)-2,2,2-trichloroethane (DDT) that is one of the most problematic persistent organic pollutants (POPs) [108]. The controlled-potential electrolysis of DDT was performed at $-1.4 \mathrm{~V}$ vs $\mathrm{Ag} / \mathrm{AgCl}$ in the presence of $\mathbf{1}$ in $\mathrm{DMF} / n-\mathrm{Bu}_{4} \mathrm{NClO}_{4}$. The DDT was converted to $1,1-\mathrm{bis}(4-$ chlorophenyl)-2,2-dichloroethane (DDD), 1,1-bis(4-chlorophenyl)-2,2-dichloroethylene (DDE), 1-chloro-2,2-bis(4-chlorophenyl)ethylene (DDMU), and 1,1,4,4-tetrakis(4-chlorophenyl)2,3-dichloro-2-butene (TTDB, $E / Z$ ) through dechlorination (Scheme $8 \mathrm{~b}$ ) [109]. A turnover number of 82 based on 1 was achieved. Mechanistic investigation revealed that the electrochemically generated $\mathrm{Co}(\mathrm{I})$ species of $\mathbf{1}$ participated in the dechlorination. To recycle the catalyst, ionic liquids are promising solvents due to their excellent electronic conductivity and nonvolatility. Thus, 1-butyl-3-methylimidazolium tetrafluoroborate ([bmim $\left.]\left[\mathrm{BF}_{4}\right]\right)$ was utilized as the solvent in the dechlorination of DDT [110]. During the extraction process, the product and $\mathbf{1}$ were separated in the organic solvent and ionic liquid layers, respectively. The ionic liquid layer could be recycled for further reactions. More interestingly, the catalytic ability of $\mathbf{1}$ increased nearly four times the reaction using DMF as solvent.
This was consistent with the Hughes-Ingold prediction of solvent polarity effects on reaction rates [111].

We also developed a visible-light-driven catalytic system for the dechlorination of DDT using $\mathbf{1}$ as catalyst and $\left[\mathrm{Ru}(\mathrm{bpy})_{3}\right] \mathrm{Cl}_{2}$ as photosensitizer [102]. The redox potential of $\left[\mathrm{Ru}(\mathrm{bpy})_{3}\right] \mathrm{Cl}_{2}$ for $\mathrm{Ru}(\mathrm{II}) / \mathrm{Ru}(\mathrm{I})$ couple is $-1.35 \mathrm{~V}$ vs SCE in $\mathrm{CH}_{3} \mathrm{CN}$. Thus, 1 was reduced to the $\mathrm{Co}(\mathrm{I})$ species by the photosensitizer in the presence of triethanolamine (TEOA) as sacrificial reductant on irradiation with a $500 \mathrm{~W}$ tungsten lamp in ethanol. DDT was successfully converted to DDD, DDE, and $\operatorname{TTDB}(E / Z)$. The recycled use of $\mathbf{1}$ and $\left[\mathrm{Ru}(\mathrm{bpy})_{3}\right] \mathrm{Cl}_{2}$ was also achieved using an ionic liquid as the reaction medium [103]. Recently, we have found that cyclometalated iridium(III) complexes such as Irdfppy [112] are superior to $\left[\mathrm{Ru}(\mathrm{bpy})_{3}\right] \mathrm{Cl}_{2}$ in terms of their photosensitization abilities in visible-light-driven $B_{12}$ catalytic systems (Scheme 9) [104]. This was probably due to the gradual decomposition of $\left[\mathrm{Ru}(\mathrm{bpy})_{3}\right] \mathrm{Cl}_{2}$ under visible light irradiation. This is consistent with the report by Yoon et al. in which light irradiation to $\mathrm{Ru}(\mathrm{bpy}) 3^{2+}$ resulted in rapid decomposition during the photocatalytic reaction [113]. It was remarkable that a significantly high turnover number based on $\mathbf{1}$ $(10,880)$ was obtained in the prolonged reaction with Irdfppy. Quenching experiments with time-resolved photoluminescence spectroscopy revealed that the oxidative quenching of the excited state of Irdfppy favorably proceeds over the reductive quenching mechanism. The combination of $\mathbf{1}$ and Irdfppy offers the best choice for the dechlorination of DDT among our lightdriven systems in terms of both catalytic activity and visiblelight harvesting.

In relation to the reactivity of $\mathbf{1}$ with DDT, interesting reactions of trichlorinated organic compounds have recently been investigated [100,114]. The $\mathrm{B}_{12}-\mathrm{TiO}_{2}$ hybrid catalyst converted trichlorinated organic compounds into esters and amides by UV light irradiation in the presence of oxygen, whereas dichlorostilbenes ( $E$ and $Z$ forms) were formed under nitrogen atmosphere from benzotrichloride [100]. It was noticeable that an oxygen switch in dechlorination was successfully demonstrated. A benzoyl chloride was identified as an intermediate of the esters and amides. The aerobic electrolysis of trichlorinated organic compounds was also mediated by $\mathbf{1}$ to yield esters and amides [114]. These reactions are important in terms of fine chemical production from trichlorinated organic compounds through easy operations (i.e., in air at room temperature).

\section{Radical-involved organic synthesis}

$\mathrm{B}_{12}$ derivatives can mediate various molecular transformations in addition to the above three-type catalytic reactions. In particular, alkylated complexes can generate radicals through the cleavage of the $\mathrm{Co}$ (III)-C bonds upon light irradiation, heating, 


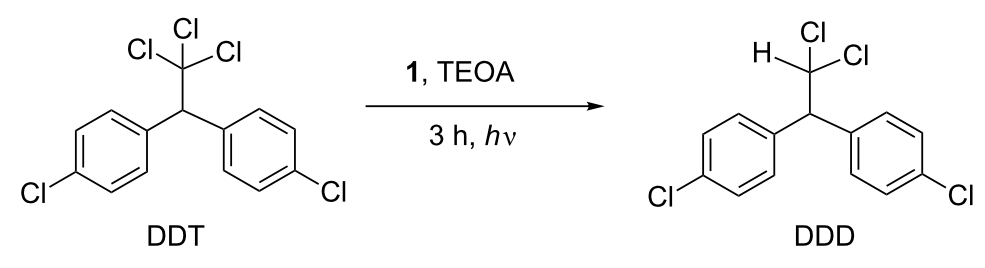

photosensitizer ( 0.128 equiv vs 1$)$
yield
turnover number based on 1

conversion

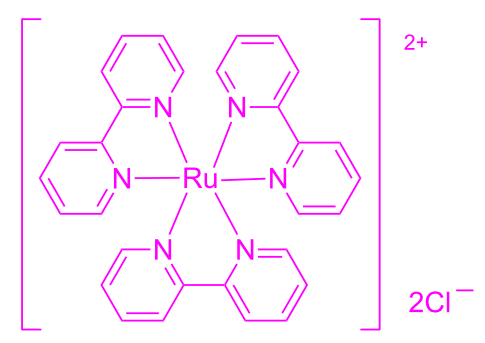

$\left[\mathrm{Ru}(\mathrm{bpy})_{3}\right] \mathrm{Cl}_{2}$

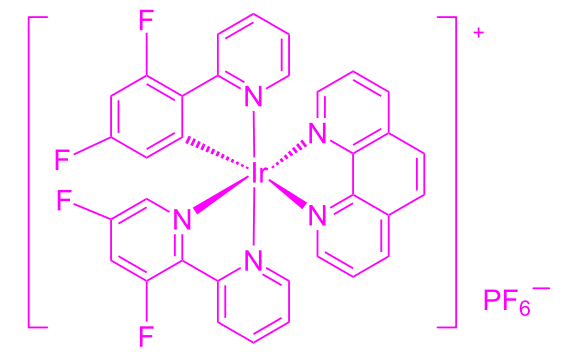

Irdfppy

$100 \%$

$93 \%$

279

Scheme 9: Visible-light-driven dechlorination of DDT using 1 in the presence of photosensitizers.

or electrochemical reduction. In addition, the corrin-ring of the $\mathrm{B}_{12}$ derivatives is tolerant to free radicals, as described above. Thus, alkylated complexes have been used for radical-mediated organic synthesis such as halide coupling, alkene coupling, and addition to double bonds [7,26,27]. In particular, the Co(III) form of $\mathbf{1}$ has recently been found to catalyze atom transfer radical addition of alkyl halides to olefins (phenyl vinyl sulfone and acrylates) in the presence of $\mathrm{NaBH}_{4}$ [115]. In addition, a new light-driven method for generating acyl radicals from 2-Spyridyl thioesters was developed through the use of vitamin $\mathrm{B}_{12}$ [116]. Furthermore, cobalester, an amphiphilic vitamin $B_{12}$ derivative with six ester groups and a nucleotide loop, has recently been developed to show good catalytic activity for $\mathrm{C}-\mathrm{C}$ bond forming reactions [117,118].

The above-mentioned visible-light-driven system composed of 1, and Irdfppy system was used for radical-mediated isomerization reactions. Visible-light irradiation of diethyl 2-bromomethyl-2-phenylmalonate produced the phenylmigrated product (Scheme 10) [104]. The product distribution highly depended on the solvents. The yield of phenyl-migrated products relative to those of simple reduced products significantly increased in $\mathrm{PhCN}$, a poor hydrogen radical donor solvent, compared with those in $\mathrm{EtOH}$ and $\mathrm{CH}_{3} \mathrm{CN}$. Similar phe-<smiles>CCOC(=O)CC(CBr)(c1ccccc1)C(CBr)(C(=O)OCC)C(=O)OCC</smilesturnover number
based on 1

219<smiles>CCOC(=O)C(Cc1ccccc1)C(Cc1ccccc1)C(C)(C(=O)OCC)C(=O)OCC</smiles>

reduced product conversion $95 \%$

$23 \%$
Ph-migrated

product

product ratio

$50 \%$ 
nyl migration was achieved in the UV-light-driven system of the $\mathrm{B}_{12}-\mathrm{TiO}_{2}$ hybrid catalyst [96-98]. The involvement of a radical species was confirmed by the spin-trapping technique followed by the ESR measurements.

The $\mathrm{B}_{12}-\mathrm{TiO}_{2}$ hybrid catalyst also mediated the ring-expansion reactions of alicyclic ketones with carboxylic ester and bromomethyl groups (Scheme 11) [96,98]. The products involving six-, seven-, and eight-membered rings were obtained through isomerization with 1,2-migration of the ester groups. The $\mathrm{B}_{12}-\mathrm{TiO}_{2}$ hybrid catalyst can be regarded as a good alternative for conventional radical-involved organic syntheses using tin compounds.

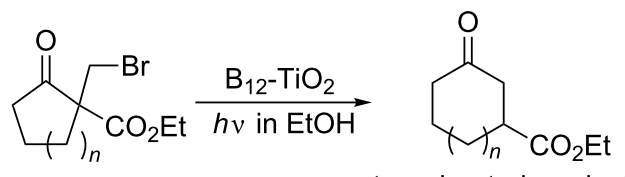
ester-migrated product

$\begin{array}{cccc} & & \text { yield } & \begin{array}{c}\text { turnover number } \\ \text { based on } \mathrm{B}_{12}\end{array} \\ n=1 & 10 \mathrm{~h} & 80 \% & 198 \\ n=2 & 12 \mathrm{~h} & 77 \% & 191 \\ n=3 & 13 \mathrm{~h} & 80 \% & 198\end{array}$

Scheme 11: Ring-expansion reactions mediated by the $\mathrm{B}_{12}-\mathrm{TiO}_{2}$ hybrid catalyst with UV-light irradiation.

Recently, we discovered that the $\mathrm{B}_{12}$ derivative $\mathbf{1}$ can mediate trifluoromethylation and perfluoroalkylation of aromatic and heteoaromatic compounds by means of electrolysis $[119,120]$. Introducing trifluoromethyl and perfluoroalkyl groups $\left(\mathrm{R}_{\mathrm{F}}\right)$ into organic compounds is an important target in organic synthesis because the corresponding fluoroalkylated molecules have received significant interest because of their metabolic stability and superior electron-withdrawing and lipophilic properties [121]. The controlled-potential electrolysis of cost-effective fluoroalkylating reagents with carbon-iodine bonds $\mathrm{R}_{\mathrm{F}} \mathrm{I}$ $\left(\mathrm{R}_{\mathrm{F}}=\mathrm{CF}_{3}, n-\mathrm{C}_{3} \mathrm{~F}_{7}, n-\mathrm{C}_{4} \mathrm{~F}_{9}, n-\mathrm{C}_{8} \mathrm{~F}_{17}\right.$, and $\left.n-\mathrm{C}_{10} \mathrm{~F}_{21}\right)$ was carried out at $-0.80 \mathrm{~V}$ vs $\mathrm{Ag} / \mathrm{AgCl}$ in the presence of $\mathbf{1}$ in methanol/ $n$ - $\mathrm{Bu}_{4} \mathrm{NClO}_{4}$ to form $\mathrm{Co}(\mathrm{III})-\mathrm{R}_{\mathrm{F}}$ complexes with deiodination. These complexes released $\mathrm{R}_{\mathrm{F}}$ radicals on the Co(III)-bond cleavage through visible-light irradiation. The resultant radicals reacted with aromatic reagents to form the target products through direct $\mathrm{C}-\mathrm{H}$ functionalization (Scheme 12).

\section{Conclusion}

In this review, we described biomimetic and bioinspired catalytic reactions with $B_{12}$ enzyme functions, with a classification into the corresponding three enzyme subfamilies. A variety of

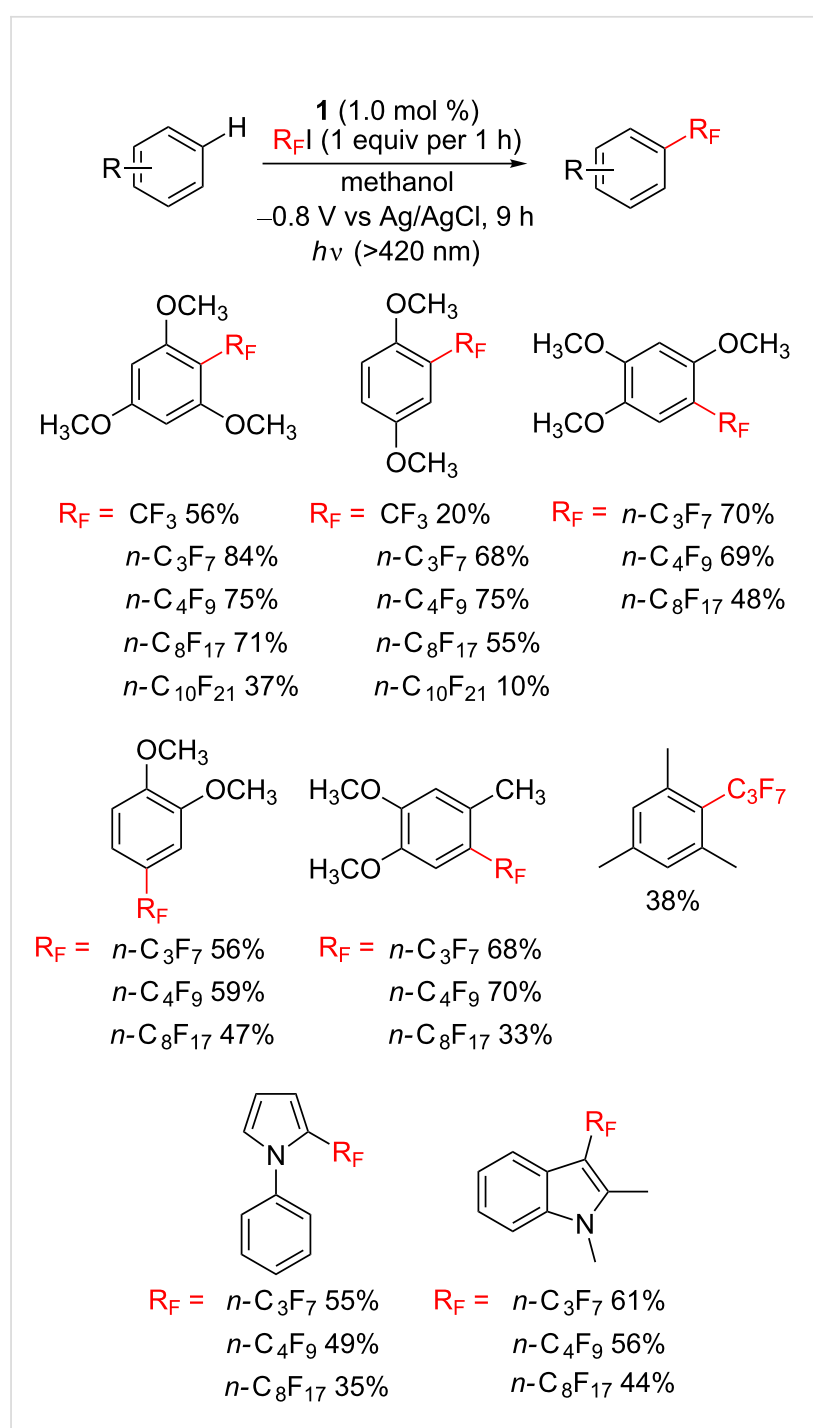

Scheme 12: Trifluoromethylation and perfluoroalkylation of aromatic compounds achieved through electrolysis with catalyst 1 .

$\mathrm{B}_{12}$ enzymes mediate various molecular transformations, in conjunction with other enzymes. Bound apoenzymes maximize the potential ability of $\mathrm{B}_{12}$ as a molecular catalyst. We conceptually broke up natural systems involving $\mathrm{B}_{12}$ enzymes into pieces and artificially assembled them again in a unique fashion. The resultant biomimetic and bioinspired systems provide new insights into designing catalytic systems in terms of green and eco-friendly reactions.

\section{Acknowledgements}

This work was partially supported by JSPS KAKENHI Grant Number JP18H04265 in Precisely Designed Catalysts with Customized Scaffolding and Grant Number JP16H04119. The authors would like to thank Enago (http://www.enago.jp) for the English language review. 


\section{ORCID ${ }^{\circledR}$ iDs}

Yoshio Hisaeda - https://orcid.org/0000-0001-9196-8006

\section{References}

1. Kräutler, B. In Vitamin $B_{12}$ and $B_{12}$-Proteins; Kräutler, B.; Arigoni, D.; Golding, B. T., Eds.; Wiley-VCH: Weinheim, 1998. doi:10.1002/9783527612192

2. Wohlfarth, G.; Diekert, G. In Chemistry and Biochemistry of $B_{12}$; Banerjee, R., Ed.; Wiley-Interscience: New York, 1999.

3. Banerjee, R.; Ragsdale, S. W. Annu. Rev. Biochem. 2003, 72, 209-247. doi:10.1146/annurev.biochem.72.121801.161828

4. Kräutler, B. Biochem. Soc. Trans. 2005, 33, 806-810. doi:10.1042/BST0330806

5. Gruber, K.; Puffer, B.; Kräutler, B. Chem. Soc. Rev. 2011, 40, 4346-4363. doi:10.1039/c1cs15118e

6. Brown, K. L. Chem. Rev. 2005, 105, 2075-2150. doi:10.1021/cr030720z

7. Giedyk, M.; Goliszewska, K.; Gryko, D. Chem. Soc. Rev. 2015, 44, 3391-3404. doi:10.1039/C5CS00165J

8. Dereven'kov, I. A.; Salnikov, D. S.; Silaghi-Dumitrescu, R.; Makarov, S. V.; Koifman, O. I. Coord. Chem. Rev. 2016, 309, 68-83. doi:10.1016/j.ccr.2015.11.001

9. Waddington, M. D.; Finke, R. G. J. Am. Chem. Soc. 1993, 115, 4629-4640. doi:10.1021/ja00064a026

10. Kräutler, B.; Keller, W.; Kratky, C. J. Am. Chem. Soc. 1989, 111, 8936-8938. doi:10.1021/ja00206a037

11. Schrauzer, G. N.; Deutsch, E.; Windgassen, R. J. J. Am. Chem. Soc. 1968, 90, 2441-2442. doi:10.1021/ja01011a054

12. Tackett, S. L.; Collat, J. W.; Abbott, J. C. Biochemistry 1963, 2, 919-923. doi:10.1021/bi00905a004

13. Hill, H. A. O.; Pratt, J. M.; O'Riordan, M. P.; Williams, F. R.; Williams, R. J. P. J. Chem. Soc. A 1971, 1859-1862. doi:10.1039/j19710001859

14. Burris, D. R.; Delcomyn, C. A.; Smith, M. H.; Roberts, A. L. Environ. Sci. Technol. 1996, 30, 3047-3052. doi:10.1021/es960116o

15. Glod, G.; Angst, W.; Holliger, C.; Schwarzenbach, R. P. Environ. Sci. Technol. 1997, 31, 253-260. doi:10.1021/es9603867

16. McCauley, K. M.; Pratt, D. A.; Wilson, S. R.; Shey, J.; Burkey, T. J.; van der Donk, W. A. J. Am. Chem. Soc. 2005, 127, 1126-1136. doi:10.1021/ja048573p

17. Gantzer, C. J.; Wackett, L. P. Environ. Sci. Technol. 1991, 25 715-722. doi:10.1021/es00016a017

18. Krone, U. E.; Thauer, R. K.; Hogenkamp, H. P. C.; Steinbach, K. Biochemistry 1991, 30, 2713-2719. doi:10.1021/bi00224a020

19. Fischli, A. Helv. Chim. Acta 1982, 65, 1167-1190. doi:10.1002/hlca.19820650406

20. Motwani, H. V.; Fred, C.; Haglund, J.; Golding, B. T.; Törnqvist, M. Chem. Res. Toxicol. 2009, 22, 1509-1516. doi:10.1021/tx900088w

21. Lexa, D.; Saveant, J. M. Acc. Chem. Res. 1983, 16, 235-243. doi:10.1021/ar00091a001

22. ó Proinsias, K.; Giedyk, M.; Gryko, D. Chem. Soc. Rev. 2013, 42, 6605-6619. doi:10.1039/c3cs60062a

23. Njue, C. K.; Nuthakki, B.; Vaze, A.; Bobbitt, J. M.; Rusling, J. F. Electrochem. Commun. 2001, 3, 733-736. doi:10.1016/S1388-2481(01)00255-7

24. Shey, J.; McGinley, C. M.; McCauley, K. M.; Dearth, A. S.; Young, B. T.; van der Donk, W. A. J. Org. Chem. 2002, 67, 837-846. doi:10.1021/jo0160470
25. Sun, F.; Darbre, T. Org. Biomol. Chem. 2003, 1, 3154-3159. doi:10.1039/b305782h

26. Scheffold, R.; Rytz, G.; Walder, L. Mod. Synth. Methods 1983, 3, 355-439.

27. Scheffold, R.; Abrecht, S.; Orlinski, R.; Ruf, H.-R.; Stamouli, P.; Tinembart, O.; Walder, L.; Weymuth, C. Pure Appl. Chem. 1987, 59, 363-372. doi:10.1351/pac198759030363

28. Murakami, Y.; Hisaeda, Y.; Kajihara, A. Bull. Chem. Soc. Jpn. 1989, 56, 3642-3646. doi:10.1246/bcsj.56.3642

29. Hisaeda, Y.; Shimakoshi, H. In Handbook of Porphyrin Science; Kadish, K. M.; Smith, K. M.; Guilard, R., Eds.; World Scientific: Singapore, 2010; Vol. 10, pp 313-370.

30. Werthemann, L. Dissertation, ETH Zürich (Nr. 4097); Juris Druck and Verlag: Zürich, 1968.

31. Kräutler, B.; Keller, W.; Hughes, M.; Caderas, C.; Kratky, C. J. Chem. Soc., Chem. Commun. 1987, 1678-1680. doi:10.1039/C39870001678

32. Murakami, Y.; Kikuchi, J.-i.; Hisaeda, Y.; Hayashida, O. Chem. Rev. 1996, 96, 721-758. doi:10.1021/cr9403704

33. Qiao, Y.; Tahara, K.; Zhang, Q.; Song, X.-M.; Hisaeda, Y.; Kikuchi, J.-i. Chem. Lett. 2014, 43, 684-686. doi:10.1246/cl.140025

34. Hisaeda, Y.; Masuko, T.; Hanashima, E.; Hayashi, T. Sci. Technol. Adv. Mater. 2006, 7, 655-661. doi:10.1016/j.stam.2006.08.003

35. Tahara, T.; Shimakoshi, H.; Tanaka, A.; Hisaeda, Y. Tetrahedron Lett 2007, 48, 5065-5068. doi:10.1016/j.tetlet.2007.05.092

36. Tahara, K.; Shimakoshi, H.; Tanaka, A.; Hisaeda, Y. Dalton Trans 2010, 39, 3035-3042. doi:10.1039/b923924c

37. Tahara, K.; Shimakoshi, H.; Tanaka, A.; Hisaeda, Y. Bull. Chem. Soc. Jpn. 2010, 83, 1439-1446. doi:10.1246/bcsj.20100221

38. Shimakoshi, H.; Nishi, M.; Tanaka, A.; Chikama, K.; Hisaeda, Y. Chem. Lett. 2010, 39, 22-23. doi:10.1246/cl.2010.22

39. Shimakoshi, H.; Nishi, M.; Tanaka, A.; Chikama, K.; Hisaeda, Y. Chem. Commun. 2011, 47, 6548-6550. doi:10.1039/c1cc11970b

40. Zhang, W.; Shimakoshi, H.; Houfuku, N.; Song, X.-M.; Hisaeda, Y. Dalton Trans. 2014, 43, 13972-13978. doi:10.1039/C4DT01360C

41. Xu, J.; Shimakoshi, H.; Hisaeda, Y. J. Organomet. Chem. 2015, 782, 89-95. doi:10.1016/j.jorganchem.2014.11.015

42. Hisaeda, Y.; Nishioka, T.; Inoue, Y.; Asada, K.; Hayashi, T. Coord. Chem. Rev. 2000, 198, 21-37. doi:10.1016/S0010-8545(99)00222-2

43. Shimakoshi, H.; Hisaeda, Y. Curr. Opin. Electrochem. 2018, 8, 24-30. doi:10.1016/j.coelec.2017.12.001

44. Shimakoshi, H.; Hisaeda, Y. ChemPlusChem 2017, 82, 18-29. doi:10.1002/cplu.201600303

45. Hisaeda, Y.; Tahara, K.; Shimakoshi, H.; Masuko, T. Pure Appl. Chem. 2013, 85, 1415-1426. doi:10.1351/PAC-CON-12-10-05

46. Frey, P. A. Chem. Rev. 1990, 90, 1343-1357. doi:10.1021/cr00105a014

47. Frey, P. A. Annu. Rev. Biochem. 2001, 70, 121-148. doi:10.1146/annurev.biochem.70.1.121

48. Stubbe, J. Annu. Rev. Biochem. 1989, 58, 257-285. doi:10.1146/annurev.bi.58.070189.001353

49. Stubbe, J.; van der Donk, W. A. Chem. Rev. 1998, 98, 705-762. doi:10.1021/cr9400875

50. Jordan, A.; Reichard, P. Annu. Rev. Biochem. 1998, 67, 71-98. doi:10.1146/annurev.biochem.67.1.71 
51. Sawers, G.; Watson, G. Mol. Microbiol. 1998, 29, 945-954. doi:10.1046/j.1365-2958.1998.00941.x

52. Toraya, T. Chem. Rev. 2003, 103, 2095-2128. doi:10.1021/cr020428b

53. Buckel, W.; Golding, B. T. Chem. Soc. Rev. 1996, 25, 329-337. doi:10.1039/cs9962500329

54. Murakami, Y.; Hisaeda, Y.; Ozaki, T.; Tashiro, T.; Ohno, T.; Tani, Y.; Matsuda, Y. Bull. Chem. Soc. Jpn. 1987, 60, 311-324. doi:10.1246/bcsj.60.311

55. Murakami, Y.; Hisaeda, Y.; Ozaki, T. J. Coord. Chem. 1991, 23 77-89. doi:10.1080/00958979109408244

56. Tahara, K.; Pan, L.; Yamaguchi, R.; Shimakoshi, H.; Abe, M.; Hisaeda, Y. J. Inorg. Biochem. 2017, 175, 239-243. doi:10.1016/j.jinorgbio.2017.07.021

57. Tamblyn, W. H.; Klingler, R. J.; Hwang, W. S.; Kochi, J. K. J. Am. Chem. Soc. 1981, 103, 3161-3172. doi:10.1021/ja00401a038

58. Elliot, C. M.; Hershenhart, E.; Finke, R. G.; Smith, B. L. J. Am. Chem. Soc. 1981, 103, 5558-5566. doi:10.1021/ja00408a047

59. Murakami, Y.; Hisaeda, Y.; Fan, S.-D.; Mastuda, Y. Chem. Lett. 1988, 17, 835-838. doi:10.1246/cl.1988.835

60. Murakami, Y.; Hisaeda, Y.; Fan, S.-D.; Mastuda, Y. Bull. Chem. Soc. Jpn. 1989, 62, 2219-2228. doi:10.1246/bcsj.62.2219

61. Tahara, K.; Chen, Y.; Pan, L.; Masuko, T.; Shimakoshi, H.; Hisaeda, Y. Chem. Lett. 2011, 40, 177-179. doi:10.1246/cl.2011.177

62. Deng, H.; Grunder, S.; Cordova, K. E.; Valente, C.; Furukawa, H.; Hmadeh, M.; Gándara, F.; Whalley, A. C.; Liu, Z.; Asahina, S.; Kazumori, H.; O'Keeffe, M.; Terasaki, O.; Stoddart, J. F.; Yaghi, O. M. Science 2012, 336, 1018-1023. doi:10.1126/science.1220131

63. Deshmukh, M. M.; Ohba, M.; Kitagawa, S.; Sakaki, S. J. Am. Chem. Soc. 2013, 135, 4840-4849. doi:10.1021/ja400537f

64. Yanai, N.; Uemura, T.; Inoue, M.; Matsuda, R.; Fukushima, T.; Tsujimoto, M.; Isoda, S.; Kitagawa, S. J. Am. Chem. Soc. 2012, 134, 4501-4504. doi:10.1021/ja2115713

65. Banerjee, R. V.; Frasca, V.; Ballou, D. P.; Matthews, R. G. Biochemistry 1990, 29, 11101-11109. doi:10.1021/bi00502a013

66. Matthews, R. G. Acc. Chem. Res. 2001, 34, 681-689. doi:10.1021/ar0000051

67. Gonzáles, J. C.; Peariso, K.; Penner-Hahn, J. E.; Matthews, R. G. Biochemistry 1996, 35, 12228-12234. doi:10.1021/bi9615452

68. Peariso, K.; Goulding, C. W.; Huang, S.; Matthews, R. G.; Penner-Hahn, J. E. J. Am. Chem. Soc. 1998, 120, 8410-8416. doi:10.1021/ja980581g

69. Zhou, Z. S.; Peariso, K.; Penner-Hahn, J. E.; Matthews, R. G. Biochemistry 1999, 38, 15915-15926. doi:10.1021/bi992062b

70. Schnyder, A.; Darbre, T.; Keese, R. Angew. Chem., Int. Ed. 1998, 37, 1283-1285. doi:10.1002/(SICI)1521-3773(19980518)37:9<1283::AID-ANIE1283>3 .0.CO;2-N

71. Zheng, D.; Darbre, T.; Keese, R. J. Inorg. Biochem. 1999, 73, 273-275. doi:10.1016/S0162-0134(99)00028-8

72. Wedemeyer-ExI, C.; Darbre, T.; Keese, R. Org. Biomol. Chem. 2007, 5, 2119-2128. doi:10.1039/b703421k

73. Kräutler, B.; Hughes, M.; Caderas, C. Helv. Chim. Acta 1986, 69, 1571-1575. doi:10.1002/hlca.19860690708

74. Wedemeyer-Exl, C.; Darbre, T.; Keese, R. Helv. Chim. Acta 1999, 82, 1173-1184. doi:10.1002/(SICI)1522-2675(19990804)82:8<1173::AID-HLCA1173> 3.0.CO;2-2

75. Pan, L.; Shimakoshi, H.; Hisaeda, Y. Chem. Lett. 2009, 38, 26-27. doi:10.1246/cl.2009.26
76. Pan, L.; Shimakoshi, H.; Masuko, T.; Hisaeda, Y. Dalton Trans. 2009, 9898-9905. doi:10.1039/b909163g

77. Pan, L.; Tahara, K.; Masuko, T.; Hisaeda, Y. Inorg. Chim. Acta 2011, 368, 194-199. doi:10.1016/j.ica.2011.01.004

78. Yamauchi, H.; Aminaka, Y.; Yoshida, K.; Sun, G.; Pi, J.; Waalkes, M. P. Toxicol. Appl. Pharmacol. 2004, 198, 291-296. doi:10.1016/j.taap.2003.10.021

79. Kaise, T.; Watanabe, S.; Ito, K. Chemosphere 1985, 14, 1327-1332. doi:10.1016/0045-6535(85)90153-5

80. Edmonds, J. S.; Francesconi, K. A. Experientia 1987, 43, 553-557. doi:10.1007/BF02143584

81. Edmonds, J. S. Bioorg. Med. Chem. Lett. 2000, 10, 1105-1108. doi:10.1016/S0960-894X(00)00176-1

82. Thomas, D. J.; Waters, S. B.; Styblo, M. Toxicol. Appl. Pharmacol. 2004, 198, 319-326. doi:10.1016/j.taap.2003.10.020

83. Nakamura, K.; Hisaeda, Y.; Pan, L.; Yamauchi, H. Chem. Commun. 2008, 5122-5124. doi:10.1039/b808937j

84. Nakamura, K.; Hisaeda, Y.; Pan, L.; Yamauchi, H. J. Organomet. Chem. 2009, 694, 916-921. doi:10.1016/j.jorganchem.2008.12.002

85. Holliger, C.; Wohlfarth, G.; Diekert, G. FEMS Microbiol. Rev. 1999, 22 , 383-398. doi:10.1111/j.1574-6976.1998.tb00377.x

86. Kräutler, B.; Fieber, W.; Ostermann, S.; Fasching, M.; Ongania, K.-H.; Gruber, K.; Kratky, C.; Mikl, C.; Siebert, A.; Diekert, G. Helv. Chim. Acta 2003, 86, 3698-3716. doi:10.1002/hlca.200390313

87. Bommer, M.; Kunze, C.; Fesseler, J.; Schubert, T.; Diekert, G.; Dobbek, H. Science 2014, 346, 455-458. doi:10.1126/science. 1258118

88. Payne, K. A. P.; Quezada, C. P.; Fisher, K.; Dunstan, M. S.; Collins, F. A.; Sjuts, H.; Levy, C.; Hay, S.; Rigby, S. E. J.; Leys, D. Nature 2015, 517, 513-516. doi:10.1038/nature13901

89. Francke, R.; Little, R. D. Chem. Soc. Rev. 2014, 43, 2492-2521. doi:10.1039/c3cs60464k

90. Yoshida, J.-i.; Kataoka, K.; Horcajada, R.; Nagaki, A. Chem. Rev. 2008, 108, 2265-2299. doi:10.1021/cr0680843

91. Savéant, J.-M. Chem. Rev. 2008, 108, 2348-2378. doi:10.1021/cr068079z

92. Albini, A.; Fagnoni, M. Green Chem. 2004, 6, 1-6. doi:10.1039/b309592d

93. Palmisano, G.; Augugliaro, V.; Pagliaro, M.; Palmisano, L. Chem. Commun. 2007, 3425-3437. doi:10.1039/b700395c

94. Fagnoni, M.; Dondi, D.; Ravelli, D.; Albini, A. Chem. Rev. 2007, 107, 2725-2756. doi:10.1021/cr068352x

95. Shimakoshi, H.; Sakumori, E.; Kaneko, K.; Hisaeda, Y. Chem. Lett. 2009, 38, 468-469. doi:10.1246/cl.2009.468

96. Shimakoshi, H.; Abiru, M.; Izumi, S.-i.; Hisaeda, Y. Chem. Commun. 2009, 6427-6429. doi:10.1039/b913255d

97. Shimakoshi, H.; Abiru, M.; Kuroiwa, K.; Kimizuka, N.; Watanabe, M.; Hisaeda, Y. Bull. Chem. Soc. Jpn. 2010, 83, 170-172. doi:10.1246/bcsj.20090234

98. Izumi, S.-i.; Shimakoshi, H.; Abe, M.; Hisaeda, Y. Dalton Trans. 2010, 39, 3302-3307. doi:10.1039/b921802e

99. Shimakoshi, H.; Hisaeda, Y. ChemPlusChem 2014, 79, 1250-1253. doi:10.1002/cplu.201402081

100.Shimakoshi, H.; Hisaeda, Y. Angew. Chem., Int. Ed. 2015, 54, 15439-15443. doi:10.1002/anie.201507782

101.Tian, H.; Shimakoshi, H.; Imamura, K.; Shiota, Y.; Yoshizawa, K.; Hisaeda, Y. Chem. Commun. 2017, 53, 9478-9481. doi:10.1039/C7CC04377E 
102.Shimakoshi, H.; Tokunaga, M.; Baba, T.; Hisaeda, Y. Chem. Commun. 2004, 1806-1807. doi:10.1039/b406400c 103.Shimakoshi, H.; Kudo, S.; Hisaeda, Y. Chem. Lett. 2005, 34 , 1096-1097. doi:10.1246/cl.2005.1096

104.Tian, H.; Shimakoshi, H.; Park, G.; Kim, S.; You, Y.; Hisaeda, Y. Dalton Trans. 2018, 47, 675-683. doi:10.1039/C7DT03742B

105. Tahara, K.; Hisaeda, Y. Green Chem. 2011, 13, 558-561. doi:10.1039/c0gc00478b

106. Tahara, K.; Mikuriya, K.; Masuko, T.; Kikuchi, J.-i.; Hisaeda, Y. J. Porphyrins Phthalocyanines 2013, 17, 135-141. doi:10.1142/S1088424612501398

107.Tahara, K.; Mikuriya, K.; Masuko, T.; Kikuchi, J.-i.; Hisaeda, Y. Supramol. Chem. 2016, 28, 141-150. doi:10.1080/10610278.2015.1103373

108. Hitchman, M. L.; Spackman, R. A.; Ross, N. C.; Agra, C. Chem. Soc. Rev. 1995, 24, 423-430. doi:10.1039/cs9952400423

109.Shimakoshi, H.; Tokunaga, M.; Hisaeda, Y. Dalton Trans. 2004, 878-882. doi:10.1039/b315170k

110. Jabbar, M. A.; Shimakoshi, H.; Hisaeda, Y. Chem. Commun. 2007, 1653-1655. doi:10.1039/b700725f

111.Cooper, K. A.; Dhar, M. L.; Hughes, E. D.; Ingold, C. K.; MacNulty, B. J.; Woolf, L. I. J. Chem. Soc. 1948, 2043-2049. doi:10.1039/jr9480002043

112.You, Y.; Nam, W. Chem. Soc. Rev. 2012, 41, 7061-7084. doi:10.1039/c2cs35171d

113.Akhtar, U. S.; Tae, E. L.; Chun, Y. S.; Hwang, I. C.; Yoon, K. B. ACS Catal. 2016, 6, 8361-8369. doi:10.1021/acscatal.6b02595 114.Shimakoshi, H.; Luo, Z.; Inaba, T.; Hisaeda, Y. Dalton Trans. 2016, 45, 10173-10180. doi:10.1039/C6DT00556J

115.Proinsias, K. ó; Jackowska, A.; Radzewicz, K.; Giedyk, M.; Gryko, D. Org. Lett. 2018, 20, 296-299. doi:10.1021/acs.orglett.7b03699

116. Ociepa, M.; Baka, O.; Narodowiec, J.; Gryko, D. Adv. Synth. Catal. 2017, 359, 3560-3565. doi:10.1002/adsc.201700913

117.Giedyk, M.; Fedosov, S. N.; Gryko, D. Chem. Commun. 2014, 50, 4674-4676. doi:10.1039/C4CC01064G

118.Giedyk, M.; Shimakoshi, H.; Goliszewska, K.; Gryko, D.; Hisaeda, Y. Dalton Trans. 2016, 45, 8340-8346. doi:10.1039/C6DT00355A

119. Hossain, M. J.; Ono, T.; Wakiya, K.; Hisaeda, Y. Chem. Commun. 2017, 53, 10878-10881. doi:10.1039/C7CC06221D

120.Ono, T.; Wakiya, K.; Hossain, M. J.; Shimakoshi, H.; Hisaeda, Y. Chem. Lett. 2018, 47, 979-981. doi:10.1246/cl.180355

121.Alonso, C.; Martínez de Marigorta, E.; Rubiales, G.; Palacios, F. Chem. Rev. 2015, 115, 1847-1935. doi:10.1021/cr500368h

\section{License and Terms}

This is an Open Access article under the terms of the Creative Commons Attribution License (http://creativecommons.org/licenses/by/4.0). Please note that the reuse, redistribution and reproduction in particular requires that the authors and source are credited.

The license is subject to the Beilstein Journal of Organic Chemistry terms and conditions:

(https://www.beilstein-journals.org/bjoc)

The definitive version of this article is the electronic one which can be found at:

doi:10.3762/bjoc. 14.232 